\title{
Effects of increased milking frequency on metabolism and mammary cell proliferation in Holstein dairy cows
}

\author{
F. Soberon, ${ }^{*}$ J. L. Lukas, ${ }^{*}$ M. E. Van Amburgh, ${ }^{*}$ A. V. Capuco,† D. M. Galton, ${ }^{*}$ and T. R. Overton ${ }^{* 1}$ \\ *Department of Animal Science, Cornell University, Ithaca, NY 14853 \\ †Bovine Functional Genomics Laboratory, USDA-ARS, Beltsville, MD 20705
}

\begin{abstract}
Results of previous studies have shown that increased milking frequency (IMF) during early lactation results in increased milk yield not only during the period of IMF but also after cows have returned to a decreased milking frequency. The cellular mechanisms underpinning this increased milk yield and the overall effects of IMF on metabolism have not been well characterized. The objective of this study was to determine the effects of IMF on metabolism and mammary epithelial cell proliferation in dairy cows. Thirty primiparous and 30 multiparous Holstein cows were assigned randomly at calving to 1 of 2 treatments. The control group was milked twice daily $(2 \times)$ for $119 \mathrm{~d}$, whereas the IMF group was milked 4 times daily $(4 \times)$ from $\mathrm{d} 2$ postcalving until d 21 and then $2 \times$ from d 22 until d 119 . Overall milk yield did not differ between treatments throughout the $119 \mathrm{~d}$ monitored; however, the interaction of treatment by week was significant in that IMF cows yielded $4.8 \mathrm{~kg} / \mathrm{d}$ more milk than control cows during wk 2 and 3 and had similar levels of milk yield during the remainder of the study period. Reanalysis of data excluding data from cows subjected to mammary biopsy suggested that the mammary biopsy procedure contributed to the lack of overall responses of milk yield, but that responses overall to IMF were greater in primiparous cows compared with multiparous cows. Plasma nonesterified fatty acid concentrations were elevated in multiparous cows subjected to IMF during the period of IMF, but were not influenced by treatment in primiparous cows. Plasma $\beta$-hydroxybutyrate concentrations were not affected by treatment. Mammary tissue was collected by biopsy in a subset of cows $(\mathrm{n}=8$ cows per parity and treatment) at calving and at $\mathrm{d} 21$ and 75 postpartum and used for immunohistochemical localization of the cell proliferation antigen, Ki67. Effects of treatment on mammary epithelial cell proliferation were not significant, suggesting that other
\end{abstract}

Received May 1, 2009.

Accepted October 7, 2009.

${ }^{1}$ Corresponding author: tro2@cornell.edu mechanisms must be responsible for carryover effects of IMF on lactational performance.

Key words: increased milking frequency, dairy cow, mammary cell proliferation

\section{INTRODUCTION}

Increased milking frequency (IMF) of dairy cows during early lactation has been demonstrated to increase milk yield not only during the treatment period but throughout lactation (Bar-Peled et al., 1995; Hale et al., 2003; Dahl et al., 2004; Wall and McFadden, 2007; Soberon et al., 2008). In addition, some studies have reported decreased SCC in cows subjected to early lactation IMF (Smith et al., 2002; Dahl et al., 2004), suggesting that early lactation IMF may improve udder health. Other authors have reported no effects of early lactation IMF on SCC or udder health (Bar-Peled et al., 1995; Hale et al., 2003; Wall and McFadden, 2007).

Few studies have focused on the effects of IMF on energy metabolism. However, effects of early lactation IMF on indicators of energy metabolism such as plasma concentrations of BHBA and NEFA as well as BCS and BW have been reported. Andersen et al. (2004) compared plasma concentrations of BHBA and NEFA of cows milked twice daily $(\mathbf{2} \times)$ versus cows milked $3 \times$ during the first 8 wk postpartum. Cows milked $3 \times$ had $19 \%$ higher plasma BHBA concentrations than cows milked $2 \times$, but plasma concentrations for NEFA did not differ between milking frequencies. Another study compared cows milked $2 \times$ to cows milked $4 \times$ during the first $21 \mathrm{~d}$ and $2 \times$ thereafter and reported that cows milked $4 \times$ tended to have higher circulating BHBA, but did not change the proportion of cows categorized as subclinically ketotic or affect circulating NEFA concentrations (Fernandez et al., 2004). Hale et al. (2003) reported that early lactation IMF $(4 \times)$ did not result in differences in BCS compared with $2 \times$ controls; however, Bar-Peled et al. (1995) reported that $6 \times$ milking decreased BCS of cows compared with the $3 \times$ control treatment.

Although multiple studies have focused on performance or udder health of cows subjected to early lacta- 
tion IMF, few studies have focused on the underlying potential cellular mechanisms for carryover milk yield responses to IMF. If there is an increase or a reduction in milk synthesis, it likely would be caused by an increase or a reduction in cell number or in secretory activity per cell (Capuco et al., 2001).

Norgaard et al. (2005) compared mammary cell proliferation and apoptosis when cows were fed high or low energy diets in conjunction with $2 \times$ or $3 \times$ milking for 8 wk followed by $2 \times$ thereafter. In that study, cows fed the high energy diet had increased milk yield, and $3 \times$ milking tended to increase milk yield during the first $8 \mathrm{wk}$; there was no difference in milk yield between milking intensity groups after wk 8. Norgaard et al. (2005) did not find differences among groups for DNA concentrations in mammary gland tissue. However, cows consuming the high energy diet had $8.6 \%$ more proliferating cells at wk 8 than cows fed the low energy diet, and apoptotic indices did not differ among treatments. Furthermore, varying milking frequency did not affect cell proliferation or apoptosis at wk 8 or 16 . Results from half-udder studies (Hillerton et al., 1990; Wall and McFadden, 2007) further support the concept that the mechanisms underpinning responses to IMF must be regulated locally.

The objectives of this experiment were to determine the effects on energy metabolism and mammary cell proliferation of cows milked $4 \times$ during the first $21 \mathrm{~d}$ and $2 \times$ thereafter compared with cows milked $2 \times$ during the entire period. These effects were evaluated by measuring changes in plasma metabolites, BCS, and BW, as well as mammary cell proliferation through determination of the labeling index for Ki67 antigen.

\section{MATERIALS AND METHODS}

\section{Animals, Treatments, and Sampling}

The Cornell University Institutional Animal Care and Use Committee approved all procedures involving animal use before the commencement of the experiment. The study started in January 2007 and ended in November 2007. Holstein cows $(\mathrm{n}=60)$ were assigned randomly to either a $2 \times$ or $4 \times$ milking treatment starting $1 \mathrm{~d}$ after parturition. Half of the cows were multiparous $(\mathrm{n}=30)$ and the other half were primiparous $(\mathrm{n}=$ 30). A total of 15 multiparous cows and 15 primiparous cows were assigned to the $4 \times$ milking group and 15 multiparous cows and 15 primiparous cows were used as $2 \times$ controls. All cows were milked at 0900 and 2030 $\mathrm{h}$, and the cows assigned to the IMF treatment were milked again at $1600 \mathrm{~h}$ and $0400 \mathrm{~h}$. After d 21 postpartum, all cows were milked $2 \times$ until $119 \mathrm{~d}$ of lactation.
Cows were housed in individual tiestalls throughout the experiment.

Milk weights were collected electronically at every milking, and milk samples were collected once weekly from all milkings and composited into a single weekly sample. The composite sample was analyzed for content of milk fat, true protein, SCC, lactose, and MUN using mid infrared spectroscopy according to AOAC (2000) methods (DairyOne Cooperative, Ithaca, NY).

All cows were fed the same diet (Table 1) for ad libitum intake once daily at $0900 \mathrm{~h}$. Amounts of feed offered and refused were recorded daily. A weekly sample of the TMR was dried at $55^{\circ} \mathrm{C}$ and the weekly DM content of the TMR was used to calculate DMI. Weekly samples were ground through a $2-\mathrm{mm}$ screen in a Wiley mill and used to prepare 4-wk composite samples that were analyzed using wet chemistry techniques (Dairy One Cooperative Inc., Ithaca, NY) for DM (method 930.15; AOAC, 2000), CP (method 990.03; AOAC, 2000), ADF and NDF (Van Soest et al., 1991), acid detergent insoluble CP (Licitra et al., 1996), and macroand microminerals (Sirois et al., 1994).

Body weights were measured for each cow on $1 \mathrm{~d} / \mathrm{wk}$ after the $0900 \mathrm{~h}$ milking. Body condition scores were assessed by 3 individuals on the same day using a 1 to 5 scale (Wildman et al., 1982); BCS values from the 3 individuals were averaged before statistical analysis.

\section{Plasma and Tissue Sampling and Analysis}

Blood samples were collected via venipuncture of the coccygeal vein or artery into evacuated test tubes containing sodium heparin (BD Vacutainer, Becton Dickinson, Franklin Lakes, NJ) within the first $24 \mathrm{~h}$ after parturition, 3 times per week for the first $21 \mathrm{~d}$ postpartum, and twice weekly thereafter until $56 \mathrm{~d}$ postpartum. All blood samples were collected starting at $0800 \mathrm{~h}$ and before the morning feeding. Blood samples were centrifuged $\left(2,800 \times g, 15 \mathrm{~min}, 4^{\circ} \mathrm{C}\right)$; plasma was aliquoted into microcentrifuge tubes and stored at $-20^{\circ} \mathrm{C}$ until analysis.

Plasma NEFA concentrations were analyzed by enzymatic analysis (NEFA-C; Wako Pure Chemical Industries, Osaka, Japan) using modifications described by McCutcheon and Bauman (1986). Plasma BHBA concentrations were determined by enzymatic analysis (BHBA dehydrogenase; kit \#310, Sigma Chemical Co., St. Louis, MO).

Mammary biopsies were conducted on 8 multiparous cows and 8 primiparous cows within each treatment group within $24 \mathrm{~h}$ postpartum, at $21 \mathrm{~d}$ postpartum, and 75 d postpartum. Biopsies (2 sites per sampled quarter) were performed using a Magnum biopsy gun (Magnum 
Table 1. Ingredient and chemical composition (DM basis) of postpartum diets

\begin{tabular}{lc}
\hline Item & \% of DM \\
\hline Ingredient & \\
Corn silage & 36.67 \\
Hay crop silage & 15.69 \\
Shelled corn, finely ground & 12.39 \\
Distillers grains & 8.66 \\
Wheat middlings & 7.05 \\
Corn germ meal & 6.03 \\
Soybean meal (47.5\% CP) & 4.21 \\
Molasses & 1.56 \\
Calcium carbonate & 0.65 \\
Whole cottonseed & 0.98 \\
Blood (flash-dried) & 1.10 \\
SucraPlex & 1.76 \\
Energy Booster $100^{1}$ & 0.62 \\
Sodium bicarbonate & 0.61 \\
Mixer fat & 0.45 \\
Urea & 0.37 \\
Salt & 0.32 \\
1000 vitamin-mineral premix ${ }^{2}$ & 0.69 \\
Magnesium oxide & 0.07 \\
Alimet ${ }^{3}$ & 0.05 \\
Soybean hulls & 0.00 \\
Calcium sulfate & 0.04 \\
Sel-Plex $2000^{4}$ & 0.01 \\
Chemical & \\
NE ${ }^{6}{ }^{6}$ Mcal/kg & \\
CP & $1.68(0.01)$ \\
Acid detergent insoluble CP & $0.87(0.22)$ \\
ADF & $19.2(1.1)$ \\
NDF & $31.4(1.6)$ \\
Ca & $0.99(0.07)$ \\
P & $0.44(0.02)$ \\
\hline
\end{tabular}

${ }^{1}$ Prilled saturated free fatty acids, MS Specialty Nutrition, Dundee, IL.

${ }^{2}$ Contained $36 \%$ Ca, $0.009 \%$ P, $0.949 \% \mathrm{Mg}, 0.839 \% \mathrm{~S}, 1,274 \mathrm{mg} / \mathrm{kg}$ of $\mathrm{Cu}, 6,040 \mathrm{mg} / \mathrm{kg}$ of $\mathrm{Mn}, 165 \mathrm{mg} / \mathrm{kg}$ of Co, $128 \mathrm{mg} / \mathrm{kg}$ of I, 7,371 mg/ $\mathrm{kg}$ of $\mathrm{Zn}, 1,204 \mathrm{IU} / \mathrm{kg}$ of vitamin A, $225 \mathrm{IU} / \mathrm{g}$ of vitamin D, and 2,305 $\mathrm{IU} / \mathrm{kg}$ of vitamin $\mathrm{E}$.

${ }^{3}$ 2-Hydroxy-4-(methylthio)-butanoic acid (Novus International, St. Louis, MO).

${ }^{4}$ Selenium yeast, Alltech Inc., Nicholasville, KY.

${ }^{5}$ Means and standard deviation of values from 10 composite samples of TMR.

${ }^{6}$ Calculated by Dairy One Cooperative (Ithaca, NY) using NRC (2001) equations.

Instrument MG1522, Bard Peripheral Vascular, Tempe, AZ). The quarter was shaved and washed with a dilute Betadine solution (Purdue Frederick, Stamford, CT) before biopsy. The site of the incision was scrubbed twice with spiral movements starting at the incision site with surgical scrub (Betadine Surgical Scrub, 7.5\% povidoneiodine; Purdue Frederick) and then rinsed with ethyl alcohol $(70 \% \mathrm{vol} / \mathrm{vol})$. Cows were administered $0.5 \mathrm{~mL}$ of the sedative xylazine hydrochloride (Rompun $2 \%$, Bayer Inc., Sarnia, Ontario, Canada) via venipuncture of the coccygeal vessels. Twenty milliliters of a local anesthetic (lidocaine- $\mathrm{HCl}, 2 \%$, Butler Animal Health, Dublin, $\mathrm{OH}$ ) was administered subcutaneously above the incision. A perpendicular incision $(\sim 2.5 \mathrm{~cm})$ was made on the outside of the quarter using a scalpel blade (size 22), a guide was inserted into the quarter (C12168, Bard TruGuide Coaxial Biopsy Needle, $11 \mathrm{G} \times 13 \mathrm{~cm}$; Bard Peripheral Vascular) on a slight downward angle and to the side. The biopsy needle was inserted into the guide (MN1216, Bard Magnum Disposable Needle, 12G $\times 16 \mathrm{~cm}$; Bard Peripheral Vascular), and 3 samples were taken. This process was repeated after repositioning the guide about $5 \mathrm{~cm}$ lateral to the first sampling site. One sample was placed into a foil pack, frozen in liquid $\mathrm{N}_{2}$, and stored at $-80^{\circ} \mathrm{C}$; another sample was fixed, frozen in liquid $\mathrm{N}_{2}$, and stored at $-80^{\circ} \mathrm{C}$; the last sample was immersed in a solution of $10 \%$ formalin in PBS for 24 $\mathrm{h}$ at $4^{\circ} \mathrm{C}$ and then transferred to a solution of $70 \%$ ethanol to be stored at $4^{\circ} \mathrm{C}$. Samples were submitted to a commercial laboratory for embedding in paraffin and tissue sectioning for immunohistochemistry (American Histolabs, Gaithersburg, MD).

\section{Immunohistochemistry and Analysis of Slides}

Immunohistochemical localization of Ki67 cell proliferation antigen was performed using a procedure modified from that described by Capuco et al. (2001). Samples were deparaffinized and hydrated in a graded series of ethanol. Slides were heated in a microwave at high power $(650 \mathrm{~W})$ in $400 \mathrm{~mL}$ of citrate buffer (10 $\mathrm{m} M$ ) in a covered glass staining dish for 5 min. Slides remained in the dish for 5 min after which they were microwaved for another 5 min. Thereafter, the slides remained in the buffer solution for a 30-min cooling period. Samples were washed in double distilled water $(3 \times 2 \mathrm{~min})$. Samples were then quenched in a $3 \% \mathrm{H}_{2} \mathrm{O}_{2}$ solution for $10 \mathrm{~min}$. Samples were washed in double distilled water $(1 \times 2 \mathrm{~min})$ and then in PBS $(3 \times 2 \mathrm{~min})$. Slides were incubated for $10 \mathrm{~min}$ with $100 \mu \mathrm{L}$ of CAS block ( $5 \%$ nonimmune goat serum in PBS), and then incubated for 60 min with MIB-1 monoclonal antibody (prediluted MIB-1, Zymed Invitrogen, Carlsbad, CA). Samples were washed in PBS with 0.05\% Tween-20 (3 $\times 2 \mathrm{~min}$ ). Slides were then incubated for $30 \mathrm{~min}$ with the secondary antibody, broad-spectrum poly horseradish peroxidase conjugate (SuperPicture HRP polymer detection kit, Zymed Invitrogen). Samples were washed in PBS with $0.05 \%$ Tween-20 $(3 \times 2$ min). Slides were incubated with DAB (3,3' diaminobenzidine) chromogen for $4 \mathrm{~min}$. Samples were washed in double distilled water $(3 \times 2 \mathrm{~min})$ and then counterstained with hematoxylin for $1 \mathrm{~min}$. Samples were washed in tap water $(1 \times 2 \mathrm{~min})$ and set in PBS until color developed $(\sim 30$ $\mathrm{s})$, rinsed in double distilled water $(1 \times 5 \mathrm{~min})$, dehydrated, and then mounted with Permaslip mounting medium (Alban Scientific, St. Louis, MO). 
Table 2. Least squares means and standard errors for milk yield and milk components during the first 17 wk of lactation for primiparous (lactation 1) or multiparous (lactation 2+) cows milked either $2 \times$ (control) for the first $21 \mathrm{~d}$ or $4 \times$ (increased milking frequency, IMF) for the first $21 \mathrm{~d}$ postpartum followed by $2 \times$ for the remainder of the period

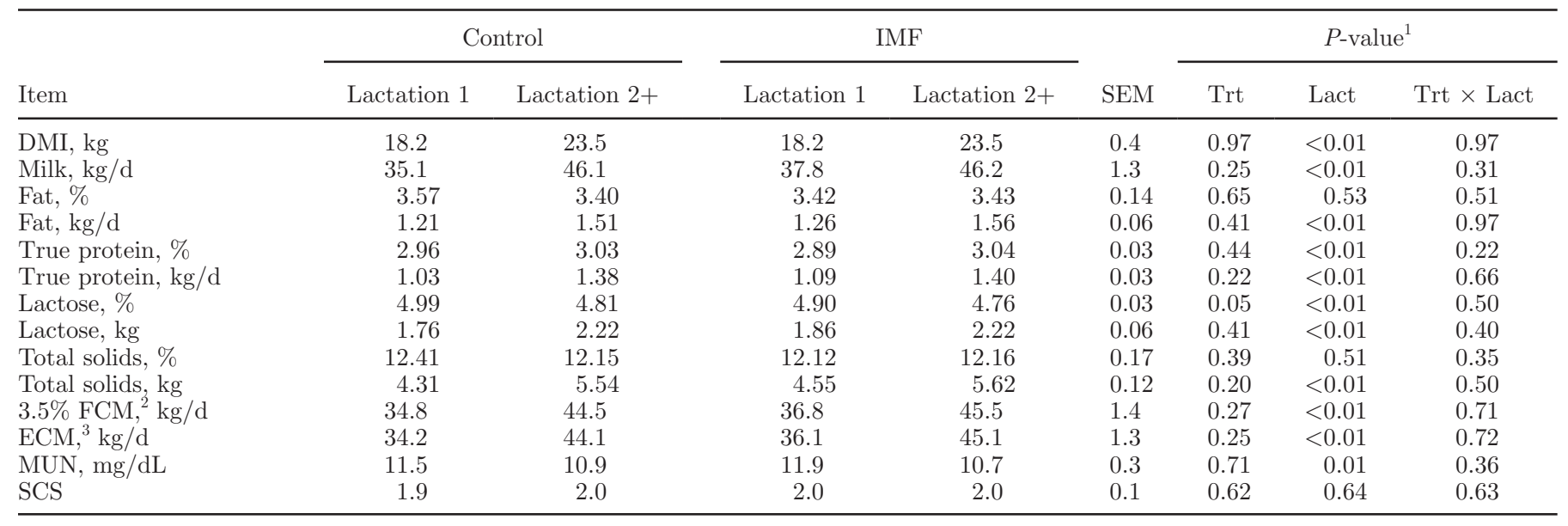

${ }^{1}$ Trt $($ treatment $)=$ control vs. IMF; Lact $=$ lactation 1 vs. lactation $2+$.

${ }^{2}$ Formula for $3.5 \%$ FCM: $[(0.4324 \times \mathrm{kg}$ of milk $)+(16.216 \times \mathrm{kg}$ of fat $)]$.

${ }^{3}$ Value corrected for $3.5 \%$ fat and $3.2 \%$ true protein using formula from NRC $(2001)[(0.3246 \times \mathrm{kg}$ of milk $)+(12.86 \times \mathrm{kg}$ of fat $)+(7.04 \times \mathrm{kg}$ of true protein)].

Slides were visualized on the microscope using a $10 \times$ objective lens out of focus to randomly select between 6 and 10 fields to be photographed; once the site was selected, a $40 \times$ objective lens was used to photograph the site. Each micrograph was analyzed and manually counted to determine the number of epithelial cells and Ki67-labeled cells per field.

\section{Statistical Analysis}

All variables measured over time were subjected to ANOVA for a completely randomized design with repeated measures using the MIXED procedures of SAS Institute (2003). The model included the fixed effects of treatment, lactation group (primiparous vs. multiparous), time (week or day), and all 2-way and 3-way interactions. For analysis of BHBA and NEFA concentrations, results from plasma collected immediately postcalving and before commencement of treatments were used as covariates. The denominator degrees of freedom were adjusted using the method of Kenward Rogers, and each model was tested using 4 different covariance structures (autoregressive order one, autoregressive order one with heterogeneous variance, compound symmetry, and compound symmetry with heterogeneous variance). The model with the lowest Akaike's information criterion was selected; in almost all cases this was the model using the autoregressive order one with heterogeneous variance structure. In a separate analysis, statistical analyses for DMI and milk yield were repeated using a data set in which all cows that had received mammary biopsies had been removed to assess the effects of treatment independent of the effects of mammary biopsy.

Difference in mammary epithelial cell-related measurements between individual biopsy days were analyzed as a completely randomized design using the MIXED procedure (SAS Institute, 2003). The model included the fixed effects of treatment, day, lactation group (primiparous vs. multiparous) and interaction of day by treatment.

Significance was declared at $P<0.05$ and trends were declared at $0.05<P<0.10$. Least squares means are presented throughout.

\section{RESULTS}

Overall results for milk yield and milk composition for multiparous and primiparous cows for the control group (milked $2 \times$ from calving until $119 \mathrm{~d}$ postpartum) and for the IMF group (milked $4 \times$ from $d 1$ to 21 and $2 \times$ from d 22 until d 119) are presented in Table 2 . The overall effects of treatment and the interaction of treatment and lactation group were not significant for any of the production-related variables measured in this experiment.

Temporal responses of cows to IMF during the first $21 \mathrm{~d}$ of lactation are presented in Figure 1. The interaction of treatment and week was significant for milk yield $(P<0.01)$ such that milk yield of cows milked $4 \times$ was increased during the first 3 wk of lactation during the period of IMF, but similar to controls thereafter. 


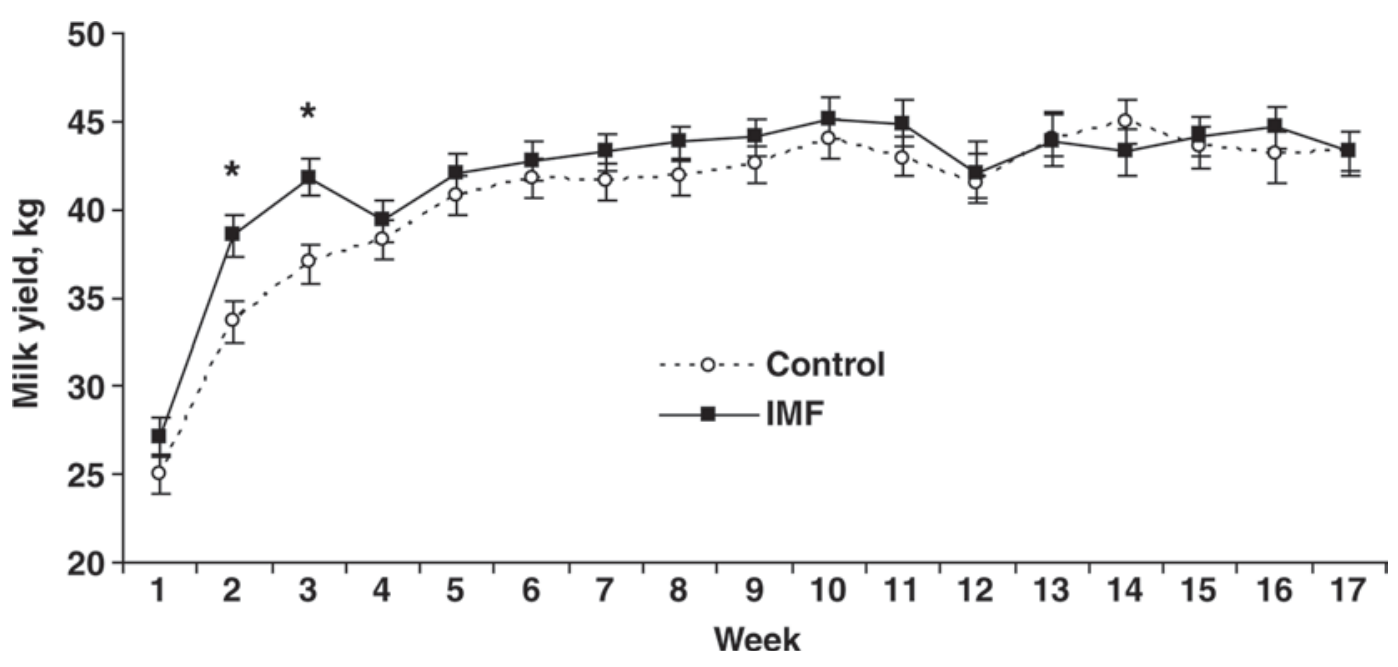

Figure 1. Least squares means and standard errors for milk yield during the first 17 wk of lactation for cows milked either $2 \times$ (control) for the first $21 \mathrm{~d}$ or $4 \times$ (increased milking frequency, IMF) for the first $21 \mathrm{~d}$ postpartum followed by $2 \times$ for the remainder of the period. The $P$-value for the effect of treatment was 0.25 , and the interaction of treatment and week was $<0.01$. Significant differences at individual time points are denoted by an asterisk.

During the first $21 \mathrm{~d}$ postpartum, cows subjected to IMF produced $4.3 \mathrm{~kg} / \mathrm{d}$ more than controls (38.1 vs. $33.9 \mathrm{~kg} / \mathrm{d} ; P<0.01)$. As described above, overall milk yield during the first $17 \mathrm{wk}$ of lactation for cows subjected to IMF was not affected by treatment (42.0 vs. $40.6 \mathrm{~kg} / \mathrm{d} ; P=0.25)$.

Statistical analysis was also conducted using only data from cows that were not biopsied because of the potential that mammary biopsies conducted on $\mathrm{d} 21$ and 75 postpartum on the subset of cows could have affected milk yield; results are reported in Figure 2. Although overall effects of treatment were not significant $(P=0.36)$, there was an interaction of treatment and lactation group $(P<0.01)$ such that early lactation IMF increased the overall milk yield of primiparous cows $(34.2 \mathrm{~kg} / \mathrm{d}$ for control vs. $40.1 \mathrm{~kg} / \mathrm{d}$ for IMF) but not multiparous cows $(50.1 \mathrm{~kg} / \mathrm{d}$ for control vs. 47.1 for IMF). Furthermore, there was a trend for an interaction of treatment, lactation group, and week $(P=0.07)$ such that milk yield increased consistently throughout the experimental period in primiparous cows, whereas IMF increased milk yield during early lactation in multiparous cows but appeared to result in decreased persistency after the treatment period (Figure 2).

With the exception of lactose percentage, overall differences in percentages or yields of milk components

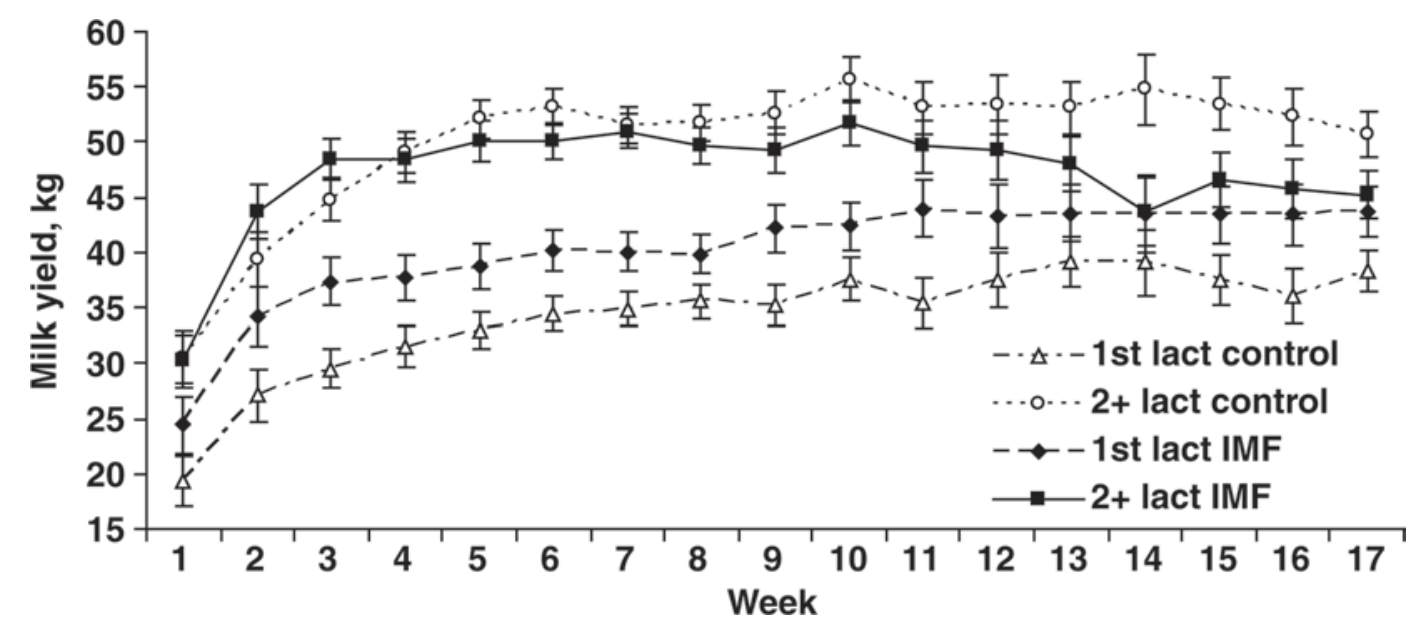

Figure 2. Least squares means and standard errors for milk yield during the first 17 wk of lactation for multiparous (2+ lact) and primiparous (1st lact) cows milked either $2 \times$ (control) for the first $21 \mathrm{~d}$ or $4 \times$ (increased milking frequency, IMF) for the first $21 \mathrm{~d}$ postpartum followed by $2 \times$ for the remainder of the period that had not received mammary biopsies. The $P$-value for the effect of treatment was 0.36 , the interaction of treatment and week was 0.02 , and the interaction between treatment and lactation group by week was 0.07 . 


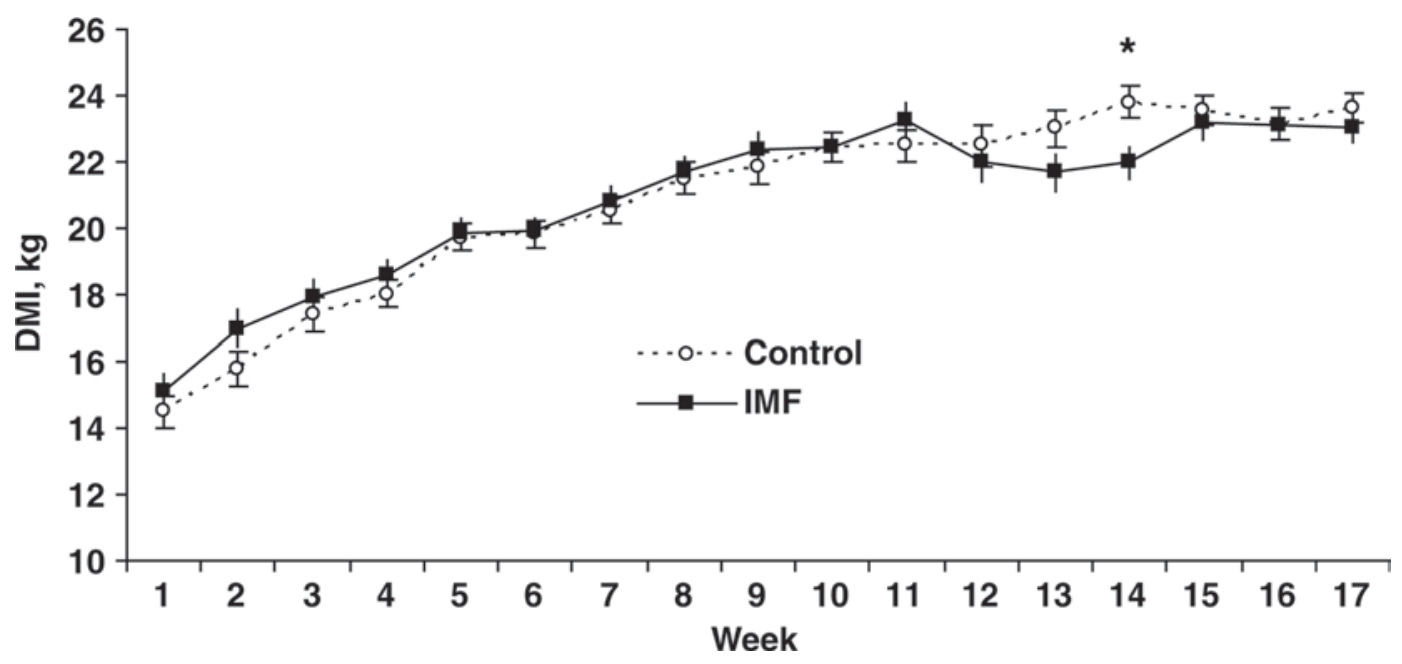

Figure 3. Least squares means and standard errors for DMI during the first 17 wk of lactation for cows milked either $2 \times$ (control) for the first $21 \mathrm{~d}$ or $4 \times$ (increased milking frequency, IMF) for the first $21 \mathrm{~d}$ postpartum followed by $2 \times$ for the remainder of the period. The $P$-value for the effect of treatment was 0.97 , and that for the interaction of treatment and week was 0.14 . Significant differences at individual time points are denoted by an asterisk.

were not significant $(P>0.10$; Table 2$)$. However, interactions of treatment and week were significant $(P<$ 0.02 ) for yields of protein, lactose, and total solids and were increased during the first $21 \mathrm{~d}$ for cows subjected to IMF, but comparable thereafter to controls (data not shown). Overall yields of 3.5\% FCM and ECM were not affected by treatment; however, both variables had treatment by week interactions $(P<0.01)$ such that yields were increased during early lactation by IMF and were similar to controls thereafter, consistent with the response patterns to yields of milk and individual milk components described above. An interaction between treatment and week also existed $(P=0.01)$ for somatic cell linear score; this interaction appeared to be caused by high values for the IMF group at wk 4 and 14 of lactation; differences were not apparent at any other time point. Overall DMI of cows was not affected by treatment (Table 2; Figure 3). When DMI was analyzed for only the first 21 DIM, cows assigned to the
IMF treatment tended to consume $\sim 0.9 \mathrm{~kg} / \mathrm{d}$ more $\mathrm{DM}$ than controls (17.0 vs. $16.1 \mathrm{~kg} / \mathrm{d} ; P=0.08)$. Differences in BCS, BW, and calculated net energy balance (Table 3 ) were not significant $(P>0.20)$ and interactions of treatment with other terms in the model were not significant.

Overall means and temporal patterns for concentrations of plasma NEFA are reported in Table 3 and Figure 4, respectively. A 3-way interaction of treatment, lactation group, and day existed $(P<0.05)$ for plasma NEFA such that multiparous cows subjected to IMF had increased plasma NEFA during the period of IMF, but were comparable to multiparous cows milked $2 \times$ thereafter (Figure 4). Concentrations of plasma NEFA in primiparous cows were comparable between treatments throughout the study period. This interaction was the primary contributor to the overall effect of treatment $(P=0.02)$ and the interaction of treatment and lactation group $(P=0.05)$ detected for plasma

Table 3. Least squares means and standard errors for BCS, BW, energy balance, BHBA, and NEFA concentrations for primiparous (lactation 1) or multiparous (lactation $2+$ ) cows milked either $2 \times$ (control) for the first $21 \mathrm{~d}$ or $4 \times$ (increased milking frequency, IMF) for the first $21 \mathrm{~d}$ postpartum followed by $2 \times$ for the remainder of the period

\begin{tabular}{|c|c|c|c|c|c|c|c|c|}
\hline Item & \multicolumn{2}{|c|}{ Control } & \multicolumn{2}{|c|}{ IMF } & SEM & \multicolumn{3}{|c|}{$P$-value ${ }^{1}$} \\
\hline $\mathrm{BCS}$ & 3.22 & 2.80 & 3.10 & 2.80 & 0.08 & 0.43 & $<0.01$ & 0.48 \\
\hline Energy balance ${ }^{2}$ & -2.57 & -1.47 & -3.22 & -1.67 & 0.50 & 0.38 & $<0.01$ & 0.64 \\
\hline $\mathrm{NEFA}, \mu \mathrm{Eq} / \mathrm{L}$ & 563 & 468 & 583 & 679 & 49 & 0.02 & 0.99 & 0.05 \\
\hline $\mathrm{BHBA}, \mathrm{mg} / \mathrm{dL}$ & 8.57 & 8.37 & 8.99 & 9.41 & 0.52 & 0.16 & 0.83 & 0.55 \\
\hline
\end{tabular}

${ }^{1}$ Trt $($ treatment $)=$ control vs. IMF; Lact $=$ lactation 1 vs. lactation $2+$.

${ }^{2}$ Net energy balance calculated using NRC (2001) equations. 


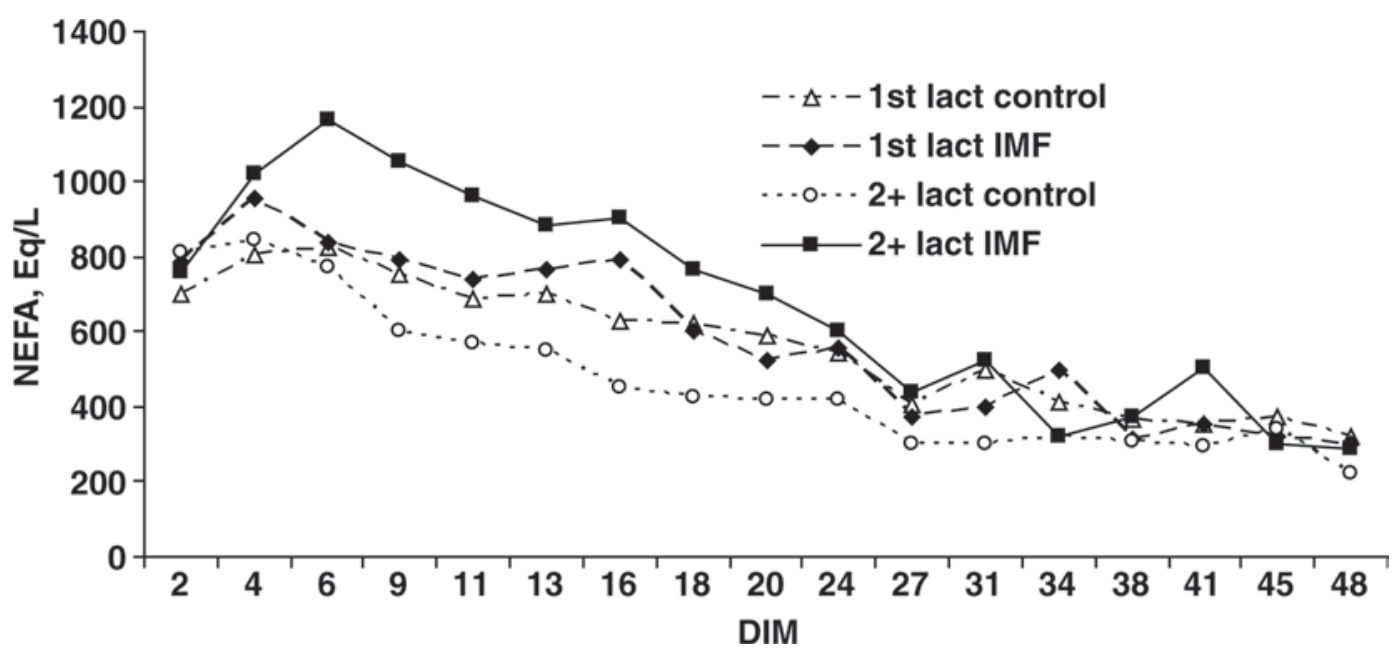

Figure 4. Least squares means and standard errors for plasma concentrations of NEFA during the first $48 \mathrm{~d}$ of lactation for multiparous (2+ lact) and primiparous (1st lact) cows milked either $2 \times$ (control) for the first $21 \mathrm{~d}$ or $4 \times$ (increased milking frequency, IMF) for the first 21 d postpartum followed by $2 \times$ for the remainder of the period. The $P$-value for the effect of treatment was 0.02 , and that for the interaction of treatment, lactation group, and day was 0.03 .

NEFA (Table 3). Despite these effects of treatment on plasma NEFA, plasma concentrations of BHBA were not affected $(P=0.16)$ by treatment (Table 3$)$.

Results for Ki67 labeling of mammary epithelial cells are presented here and in Figure 5. The percentage of Ki67-labeled epithelial cells in biopsies collected before assignment to treatment was not different between the 2 treatment groups $(2.7 \%$ for control vs. $2.1 \%$ for IMF; $P=0.54)$ or between lactation groups $(1.68 \%$ for primiparous vs. $3.08 \%$ for multiparous; $P=0.19)$. In mammary tissue collected via biopsy on d 21 and 75 postpartum (Figure 5), the percentage of Ki67-labeled cells was not affected by treatment, lactation group, or day. Moreover, 2- and 3-way interactions of treatment and lactation group with each other and with day were not significant $(P>0.10)$.

\section{DISCUSSION}

The milk yield increase for cows subjected to IMF during the treatment period was similar to that reported from our concurrent study conducted on commercial dairy farms (Soberon et al., 2008). In the current experiment, milk yield was increased by $4.3 \mathrm{~kg} / \mathrm{d}$ during the first $21 \mathrm{~d}$ for cows subjected to IMF; in the concurrent study, IMF cows increased milk yield by $4.3 \mathrm{~kg} / \mathrm{d}$ at the first test-day. In a previous study, Fernandez et al. (2004) reported an increase of $3 \mathrm{~kg} / \mathrm{d}$ during the first 2 test-days for cows subjected to IMF on commercial dairy farms. These responses in milk yield are generally lower than those described by others. Bar-Peled et al. (1995) observed an increase in milk yield of $7.3 \mathrm{~kg} / \mathrm{d}$ during the first $42 \mathrm{~d}$ for cows milked $6 \times$ compared with $3 \times$ controls; Hale et al. (2003) reported an $8.8 \mathrm{~kg} / \mathrm{d}$ in- crease in milk yield during $21 \mathrm{~d}$ of IMF for cows milked $4 \times$ compared with $2 \times$ controls, and Dahl et al. (2004) determined that cows milked $6 \times$ produced $8.4 \mathrm{~kg} / \mathrm{d}$ more milk during the first $21 \mathrm{~d}$ postpartum compared with $3 \times$ controls.

Overall milk yield responses to IMF were not significant when assessed across the 119-d experimental period. This response was not expected and is not consistent with the results from Soberon et al. (2008). In the current study, milk yield increased $4.3 \mathrm{~kg} / \mathrm{d}$ during the IMF treatment period but converged with milk production of the control group beginning at wk 4 . When data for biopsied cows were eliminated from the data set, multiparous cows had a minimal overall response to early lactation IMF, but primiparous cows subjected to early lactation IMF consistently yielded more milk than control cows throughout the study period. Because we and others had not noted a differential effect of parity on response to early lactation IMF, this may suggest that the mammary biopsy procedure used in the current study influenced the carryover milk yield responses in multiparous cows but did not obscure a treatment effect during the period of IMF. In contrast, primiparous cows may have been less sensitive to biopsy than multiparous cows and maintained a persistent increase in milk yield after the treatment period.

Consistent with the lack of milk yield response during the entire experimental period, overall differences in DMI were not significant. As expected, DMI tended to increase during the 21-d period of IMF in which milk yield was increased. Consistent with the minimal response in overall milk yield, effects of treatment on $\mathrm{BCS}, \mathrm{BW}$, or calculated energy balance were not significant. Control cows and IMF cows did not differ from 


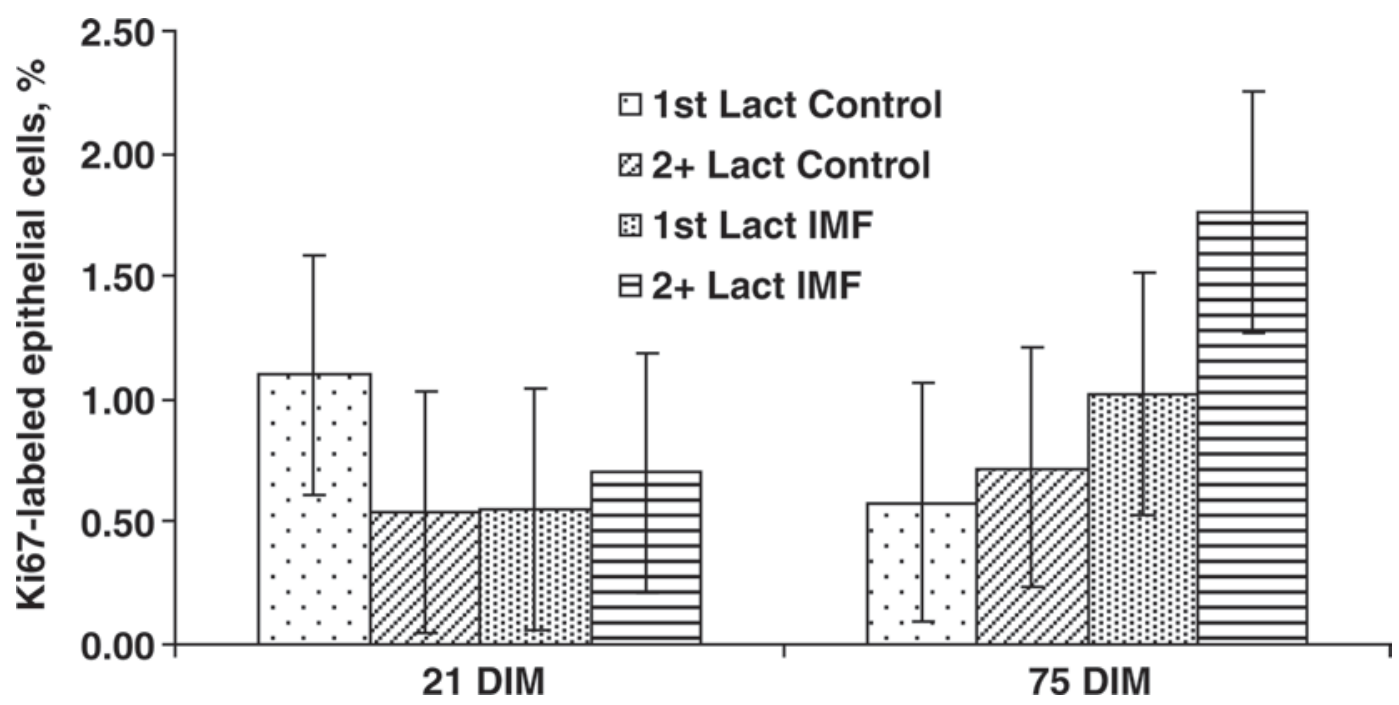

Figure 5. Least squares means and standard errors for the percentage of Ki67-labeled epithelial cells in mammary biopsies collected from primiparous (1st lact) or multiparous (2+ lact) cows milked either $2 \times$ (control) for the first $21 \mathrm{~d}$ or $4 \times$ (increased milking frequency, IMF) for the first $21 \mathrm{~d}$ postpartum followed by $2 \times$ for the remainder of the period. The $P$-value for the effect of treatment was 0.37 , that for lactation group was 0.70 , that for the effect of day was 0.33 , that for the interaction of treatment and lactation group was 0.29 , and that for the interaction of treatment by day was 0.13 .

each other in BCS or BW throughout the 18-wk period. These results are in agreement with those in Hale et al. (2003), who did not find differences in BCS between treatments.

Multiparous cows in the IMF group had higher blood concentrations of NEFA than did control cows during the period of IMF. The interaction between treatment and lactation group for NEFA levels and the trend for treatment $\times$ lactation group $\times$ week interaction for milk yield suggests a negative association of high NEFA concentrations with milk production in multiparous cows, providing a possible explanation for the lack of carryover in these cows subjected to IMF. Results from a large study conducted recently on commercial dairy farms (Ospina et al., 2009) support this concept. In that study, multiparous cows with NEFA $>0.72$ $\mathrm{mEq} / \mathrm{L}$ when sampled during d 3 to 14 postpartum had lower $(-662 \mathrm{~kg})$ mature-equivalent 305 -d projected milk yield compared with cows with lower NEFA at the time of sampling. Interestingly, in primiparous cows, elevated NEFA $(>0.57 \mathrm{mEq} / \mathrm{L})$ during the same postpartum period was associated with increased $(+482 \mathrm{~kg})$ mature-equivalent 305-d projected milk yield. These relationships appear to be consistent with patterns of response in the present experiment. Clearly, results from the present study and others show only a possible association; whether the mechanism occurs through direct effects of NEFA or whether increased NEFA is only a marker for other aspects of energy metabolism (e.g., limited glucose supply) remains uncertain.

Soberon et al. (2008) reported that 2 out of 4 farms had higher NEFA values for IMF cows, whereas differ- ences on the other 2 farms were not significant. In general, farms that had larger increases in plasma NEFA during IMF had lower milk yield responses. Fernandez et al. (2004) reported that IMF did not affect plasma NEFA concentrations. Andersen et al. (2004) reported that increasing the milking frequency from $2 \times$ to $3 \times$ during early lactation did not affect plasma NEFA values but did increase plasma BHBA. Differences in plasma BHBA between treatments in the present study were not significant.

There was no effect of IMF on mammary cell proliferation in this study. There was some variation in the percentage of Ki67-labeled cells at d 0 that might reflect some carryover from cell proliferation during the dry period. Although not significant, the percentage of labeled epithelial cells decreased from d 0 to d 21. Hale et al. (2003) noted a decrease in Ki67 labeling between d 7 and d 14 in 2 of their treatments; however, these differences were also not significant. Norgaard et al. (2005) did not observe differences in milk production or cell proliferation for cows milked $3 \times$ for 8 wk versus cows milked $2 \times$ for 8 or 16 wk. However, they reported increased proliferation of mammary epithelial cells at wk 8 postpartum in cows fed a higher energy diet.

Milk synthesis is a function of both the number and activity of mammary epithelial cells, and the number of epithelial cells depends upon the relationship between the rates of proliferation and apoptosis. Even though activity of epithelial cells and apoptotic rate were not measured in this study, the data suggest that there may be an effect of IMF on mammary cell activity and or turnover that should be characterized in future studies, 
because proliferation was not apparently different. On the basis of gene expression and histological analyses, Connor et al. (2008) reported that IMF increased angiogenesis and remodeling of the extracellular matrix in the mammary gland during the treatment period and suggested that this may be a factor in promoting or complementing an observed increase in milk yield that persists beyond the treatment period. Additional studies are necessary to fully understand the factors that contribute to local regulation of milk yield in response to IMF and the management procedures that promote these processes.

\section{CONCLUSIONS}

Early lactation IMF resulted in increased milk yield during the period of IMF treatment but minimal carryover effects on milk yield. Responses appeared to be greater in primiparous cows compared with multiparous cows, and carryover effects were apparent only in primiparous cows. In general, IMF did not affect energy metabolism, although the increased plasma NEFA concentrations in multiparous cows appeared to be associated with limited overall responses to IMF, suggesting that better responses may be achieved in management systems that allow for increased milk yield to IMF without increased negative energy balance as assessed by circulating NEFA. Effects of IMF appear to not be related to differences in mammary cell proliferation, and other potential mechanisms such as cell apoptosis and cell activity warrant investigation.

\section{ACKNOWLEDGMENTS}

The assistance of the following colleagues in implementing the study and analyzing samples is gratefully acknowledged: Kevin Harvatine (Cornell University, Ithaca, NY) for assistance with the mammary biopsy protocol, Chris Evock-Clover (ARS-USDA, Beltsville, MD) and Ramona Ehrhardt (Cornell University, Ithaca, NY) for laboratory technical assistance, and the crew at the Cornell University Dairy Teaching and Research Center for daily management of the cows and their cooperation. Partial funding for this study was provided through Federal Formula Funds allocated to the Cornell University Agricultural Experiment Station.

\section{REFERENCES}

Andersen, J. B., N. C. Friggens, T. Larsen, M. Vestergaard, and K. L. Ingvartsen. 2004. Effect of energy density in the diet and milking frequency on plasma metabolites and hormones in early lactation dairy cows. J. Vet. Med. 51:52-57.
AOAC. 2000. Official Methods of Analysis. 17th ed. Association of Official Analytical Chemists, Arlington. VA.

Bar-Peled, U., E. Maltz, I. Bruckental, Y. Folman, Y. Kali, H. Gacitua, and A. R. Lehrer. 1995. Relationship between frequent milking or suckling in early lactation and milk production of high producing dairy cows. J. Dairy Sci. 78:2726-2736.

Capuco, A. V., D. L. Wood, R. Baldwin IV, K. McLeod, and M. J. Paape. 2001. Mammary cell number, proliferation, and apoptosis during a bovine lactation: Relation to milk production and effect of bST. J. Dairy Sci. 84:2177-2187.

Connor, E. E. S. Siferd, T. H. Elsasser, C. Clover, C. P. Van Tassell, T. S. Sonstegard, V. Fernandes, and A. V. Capuco. 2008. Effects of increased milking frequency on gene expression in the bovine mammary gland. BMC Genomics doi:10.1186/1471-2164-9-362

Dahl, G. E., R. L. Wallace, R. D. Shanks, and D. Lueking. 2004. Hot topic: Effects of frequent milking in early lactation on milk yield and udder health. J. Dairy Sci. 87:882-885.

Fernandez, J., C. M. Ryan, D. M. Galton, and T. R. Overton. 2004. Effects of milking frequency during early lactation on performance and health of dairy cows. J. Dairy Sci. 82(Suppl. 1):424. (Abstr.)

Hale, S. A., A. V. Capuco, and R. E. Erdman. 2003. Milk yield and mammary growth effects due to increased milking frequency during early lactation. J. Dairy Sci. 86:2061-2071.

Hillerton, J. E., C. H. Knight, A. Turvey, S. D. Wheatley, and C. W. Wilde. 1990. Milk yield and mammary function in dairy cows milked four times daily. J. Dairy Res. 57:285-294.

Licitra, G., T. M. Hernandez, and P. J. Van Soest. 1996. Standardization of procedures for nitrogen fractionation of ruminant feeds. Anim. Feed Sci. Technol. 57:347-358.

McCutcheon, S. N., and D. E. Bauman. 1986. Effect of chronic growth hormone treatment on responses to epinephrine and thyrotropinreleasing hormone in lactating cows. J. Dairy Sci. 69:44-51.

Norgaard, J., A. Sorensen, M. T. Sorensen, J. B. Andersen, and K. Sejrsen. 2005. Mammary cell turnover and enzyme activity in dairy cows: Effects of milking frequency and diet energy density. J. Dairy Sci. 88:975-982.

NRC. 2001. Nutrient Requirements of Dairy Cattle. 7th rev. ed. Natl. Acad. Press, Washington, DC.

Ospina, P. A., D. V. Nydam, T. Stokol, and T. R. Overton. 2009 Evaluation of NEFA and $\beta$-hydroxybutyrate (BHB) as predictors of clinical disease, milk production, and reproductive performance in dairy cattle. J. Dairy Sci. 92(E. Suppl. 1):141. (Abstr.)

SAS Institute. 2003. SAS/STAT User's Guide: Statistics. Version 9 ed. SAS Inst. Inc., Cary, NC.

Sirois, P. K., M. J. Reuter, C. M. Laughlin, and P. J. Lockwood. 1994. A method for determining macro and micro elements in forages and feeds by inductively coupled plasma atomic emission spectrometry. Spectroscopist 3:6-9.

Smith, J. W., L. O. Ely, W. M. Graves, and W. D. Gilson. 2002. Effect of milking frequency on DHI performance measures. J. Dairy Sci. 85:3526-3533.

Soberon, F., C. M. Ryan, D. M. Galton, and T. R. Overton. 2008. The effects of increased milking frequency during early lactation on milk yield and milk composition on commercial dairy farms. J. Dairy Sci. 91(E-Suppl. 1):34. (Abstr.)

Van Soest, P. J., J. B. Robertson, and B. A. Lewis. 1991. Methods for dietary fiber, neutral detergent fiber, and nonstarch polysaccharides in relation to animal nutrition. J. Dairy Sci. 74:3583-3597.

Wall, E. H., and T. B. McFadden. 2007. The milk yield response to frequent milking in early lactation of dairy cows is locally regulated. J. Dairy Sci. 90:716-720.

Wildman, E. E., G. M. Jones, P. E. Wagner, R. L. Boman, H. F. Trout, and T. N. Lesch. 1982. A dairy cow body condition scoring system and its relationship to selected production variables in high producing Holstein dairy cattle. J. Dairy Sci. 65:495-501. 